\title{
The Forces Opposed to Abu Al-Abbas the Slaughter and the Mechanism of Dealing with Them
}

\author{
Shaden Mohammed Al-Wahsh ${ }^{1}$ \\ ${ }^{1}$ Al- Zaytoonah University, Jordan \\ Correspondence: Shaden Mohammed Al-Wahsh, Al- Zaytoonah University, Jordan
}

Received: July 30, 2018

Accepted: August 15, 2018

Online Published: August 31, 2018

doi:10.5539/ach.v10n2p82

URL: http://dx.doi.org/10.5539/ach.v10n2p82

\begin{abstract}
The Abbasid Call has declared its victory and the end of the Umayyad state and the beginning of the era of a new state, the Abbasid state. Abu Abbas, the first of the Abbasid caliphs, bore the burden of leadership over Ibrahim the imam, as well as the obstacles to its establishment and the various reactions that were issued in word and deed.

However, leaders in history differ in their response to attitudes from one leader to another, the presence of the opposition forces in the Abbasid state showed the caliphs mechanism of dealing with the various positions and the extent of their knack and intelligence in dealing with them, and show the hidden aspects of the personality of each of the caliphs.

Perhaps Abu Abbas the slaughter was the most prominent caliphs who suffered from the large number of opposition forces where he faced a large number of forces that threatened to remain in power, but his will and political intelligence managed to address them.

Many scholars have studied the Umayyads or the ovaries or the revolutions of the Shiites in the Abbasid period, as many have studied the leaders of such as Abu Musallam Al-Kharasani and Abu Salamah, but Abu Abbas the slaughter did not have a large presence in these studies, and this research specialized about the methods and ways that Abu Abbas the slaughter used to deal with those different forces.
\end{abstract}

Keywords: Abbasid Call, Umayyad state, forces

\section{Introduction}

The slaughter ways of dealing with the various powers when he took the Caliphate:

The title of Abu al-Abbas ("the slaughter" (note 1)), one of his most famous titles until he overcame him (a nickname was known) (1) The word was used for the first time in his sermon when he took power in his promise to increase the Kufa people's bid: (.. I will give you hundreds and hundreds; so be prepared, I am the rebel criminal..)

The incriminating is one of the scary titles that show the ferocity of Abu Abbas in confronting his opponents, historians confirm this meaning as Yacoubi says: In the description of the killer: , was quick to order the shedding of blood, he killed the Asha'ath in Morocco (82 e) ,Saleh bin Ali in Egypt, Khazm bin Khuzaymah, Hamid bin Qahtba in Iraq, and shed Abdullah bin Ali In Levant, and shed David bin Ali in Al-Hijaz, and his brother Yahya bin Mohammed in Mosul. He was, however, permitting a money-bound destination. Some historians adopted this picture of Abu Abbas and the league considers that the name of the slaughter was the result of the confusion of some historians between Abdullah bin Mohammed Abu Abbas, and his uncle Abdullah bin Ali (Abdul Aziz, 2014; Al-Masoudi, 1992; Al-Suyuti, 2005; Amin \& Islam, 2001).

Ibn Qutaiba said: " his uncle Abdullah bin Ali, who is called the slaughter of the Sham." Al-Dinuri asserts that "the slaughterer" is the title of Abdullah bin Ali his uncle and not the title of Abu Abbas. It said that the first to misunderstand was the historian (Masoudi). The title the slaughter alone does not show the true personality of this caliph, it wasn't a title for him, but was for his uncle, although he used in his sermon to mean that it will increase tender (Anonymous, n.d.).

Therefore, the title alone does not provide a picture of the mechanism that dealt with the various forces opposed to him, so it is necessary to shed light on the forces that opposed his rule and the forces that were in his class when he declared the Abbasid call, and how the slaughter dealt with it. 


\subsection{Problem of the Study}

Many scholars have studied the Umayyads or the ovaries or the revolutions of the Shiites in the Abbasid period, as many have studied the leaders of such as Abu Musallam Al-Kharasani and Abu Salamah, but Abu Abbas the slaughter did not have a large presence in these studies, and this research specialized about the methods and ways that Abu Abbas the slaughter used to deal with those different forces.

\subsection{The purpose of the Study}

This study will discuss the men of the Abbasid Call in the section that was next to Abu al-Abbas the slaughter and turned against him.

\section{Methodology}

The researcher used the qualitative approach by discussing the men in the Abbasid Call.

\subsection{People of the Abbasid Call}

The people of the Abbasid Call had unrivaled loyalty to an imam who did not know his identity and was selling them to the Muhammad family. Before the appearance of the Slaughter, one of the men of the Umayyad state who went to Qahtoba said to him: "Qahtaba said to pledge."

The man said: to Whom? He said: For the satisfaction of the family of Muhammad. The man said: This is an unknown pledge that does not have a contract.

Qahtaba said: How? He said: if the people of each country took a man from the family of Muhammad and said: satisfaction in our hands for those who sell them? He rebuff him and said, "pledge."

the man said, " I won't pledge to someone i don't know his name". The soldiers were surprised by this statement,

And he was afraid of himself, and spoiled the hearts of the soldiers

Qahtoba said: pledge to Ibrahim bin Mohammed bin Ali bin Abdullah bin Abbas bin Abdul Muttalib .... This was narrated in the talk of the attempts of Marwan bin Mohammed to know the identity of the imam. The preachers gave a binding covenant to a man whose identities were not clear to them, and the covenant was for the household, and yet there was no dispute over that person during the secret invitation, But on the contrary ... (The people of Khorasan were fighting for him, and giving themselves and their money without him, and most of them do not know him, and does not differentiate between his name and his person). And take a look at (Ibrahim Imam, while he's in an interruption at his house and retired the world, when he was in Al-Hijaz or the Levant (Farhoud, 1977).

While he had such a great army in Khorasan, they give their souls without him, he does not spend money on them, and does not give one of them a beast or a weapon. But they must pay him money, and carry him abscess every year).

They have taken these money to a man who did not know his identity, and fought in the name of a man did not know anything about him, and may be some preachers knew the identity of the Imam in the final stage of the age of the call; but that does not justify all this tender and the work for someone unknown. Therefore, it is only the preachers who bear the responsibility of allegiance to a person they did not know well, and that it is not possible to change their positions after that, whether the imam changed or changed the family that they pledged. (Apparently, Ibn al-Kirmani was not sure that the Abbasid call was on behalf of The Abbasid house, but revolted in the name of (the satisfaction of the people of the house) (Fawzi, 2003, 2006) and then revolted.

The imam relied mainly on Khorasan, which was far from the Umayyad state, and began to recover in the last period of the Umayyad rule, and is trying to regain its former status in the era of Persian civilization before the advent of Islamic rule. The imam also relied on winning the support of Khorasan during their pilgrimage to Mecca to perform the Hajj. Most of them were interested with Al-Albayt. Some of them found allegiance to members of the Al-Albayt family, which is similar to that of the Persians, which some may agree with or disagree with. My point of view stems from the loyalty and great effort that these people gave to an imam they did not yet know.

But the saying which says (the revolution kills its children) applies exactly to the Abbasid call. Immediately after the death of Abraham the Imam and the succession of Abu Abbas after him, and then to know the name of the guardian and the knowledge of the family for which the preachers came out, the word of the preachers broke out and the positions changed. Loyalty and the performance of some of the preachers weren't as the era of Ibrahim Imam.

The Caliph Abu Abbas honored the leaders of the call. He was awarded the title of Minister for a number of personalities close to him (Fawzi, 2002). However, the two most important figures who made great efforts and served in the era of the Imam and during the reign of the first successors of the Abbasid state were: Abu Musallam 
Al-Kharasani (Commander Khorasan) and Abu Salamah Al-Khallal (Commander of the Kufa), although there are other advocates with them in Khorasan and Kufa .However, these two leaders were very prominent.

But it is strange that these two characters were killed after the allegiance to Abu Abbas, and it is not known if their murder was directed by the Imam himself, as some sources indicate a plan drawn by the imam.

Masoudi says: (Demonstrated on the order of the preachers and the captains, drew to him a drawing so he recommended to work on it, and not beyond)(Fawzi, 1998). However, the text of the will (Ibn Qutaiba, 1990) contained in the book of the news of Abbas and his son does not carry an invitation to kill the preachers after the completion of the invitation to the Abbasids. Therefore, it is not possible that such liquidation is the will of the imam.

Perhaps the elimination of preachers for the needs necessitated by the nature of the positions, and the reactions that were issued by the preachers on the assumption of Abu Abbas, he had to get rid of the largest leaders in Khorasan and Kufa, taking their actions justified, and it was easy to start with Abu Salamah Khallal, He gave him a direct reason, especially since the rest of the Kufa preachers were with Abu al-Abbas the slaughter. , But for Abu Musallam al-Kharasani he hoped to get rid of him, but postponed it so much, especially that his control of Khorasan was great, and that he had great influence, and had a large army had to distinguish the power first to be unique and push it to eliminate the leaders of Khorasan one after the other, only to find himself alone, or among a few loyal followers. So the killing of Abu Muslim was delayed until Abu Jaafar al-Mansur assumed the caliphate, so Al-Mansur killed him and got rid of him. The following are the preachers who were disposed of by Abu Musallam Al-Kharasani:

Abu Salamah Khallal: Abu Salamah Hafs bin Suleiman commander of the call of the Abbasids in Kufa, when he reached Abu Abbas went to the largest leaders (Abu Salamah) and told him about the death of the imam and the commandment, hoping to receive a great support (he was from the people of Kufa, and was spending money on Men of the call) (Ibn Jarir, 1966). However, according to the accounts referred to an unexpected reaction from Abu Salamah (when he knew about the death of the Imam, he returned from the Abbasid call to the Abu Talib, may Allah be pleased with him). And (Abu Salamah concealed the order of Abu Abbas and his companions) (Ibn Tabataba, 1999).

According to this narration, the return of the Abbasids call is because he was not aware that the call to the allegiance to the family of Muhammad was intended to call the Abbasids, or that the sale of the Imam does not necessarily mean allegiance to the guardian of the Imam in his view had the right to convert the invitation to those who wanted.

Abu Salamah wanted to transfer the caliphate to Ali ibn Abi Talib son, and he prevented Abu Abbas from going out, and says to him: It is not done, and that Umayyad sons will start the war, and it is more severe than it was. Abu al-Abbas said: Abu Salamah prevented me from going out until the workers give labor and abscess

The commander (Abu Muslim Kharasani) said: God curse Abu Salamah, and I won't sit until you go out to the people, so he went out with his men to the mosque, and the prayer of the University; and ascended Abu Abbas platform ... (Ibn Qutaiba, 1990). After Abu al-Abbas took over, he began to plan to get rid of the calamities and began to exclude his followers and loyalists (Ibn Qutaiba, 1969).

Abu Abbas knew about his position to return from the invitation to the imam, especially after two months of procrastination, and has used other advocates of Kufa,so he sent Khawarizmi to the market and he was known by the preachers that he was loyal to Ibrahim Imam, so Abu Hamid Abu Tusi knew through his presence in Kufa that the Imam is in Kufa.

He was known as the Imam's commandment to Abu Abbas

(Abu Hameed Al-Tusi and with him six advocates: Abu Jahm bin Attia, Musa ibn Ka'b, Abu Ghanim Abdul Hamid bin Rabai, Salameh bin Mohammed, Abu Sharahil and Abdullah bin Bassam) (Masoudi, n.d.) to Abu Abbas and pledged with him, and took him to the mosque in Kufa, Abu Salamah tried to catch up with them, then he also pledged him and brought him to pray Friday at the Grand Mosque of Kufa (Yacoubi, 2009) to the Yacoubi: When Abu Salamah knew about the meeting of Abu Hamid and his going to pledge with the slaughter and take him to the mosque wearing black, the news reached Abu Salamah, the monk came to their right, he said: I was only showing the rightness of the matter and not doing anything (Yacoubi, 1996).

Al-Dinuri said: They mentioned that Abu Muslim knew that Abu Salamah had shown his command in Kufa. He called Muhammad and directed a man from his commanders to Kufa with two thousand knights and ordered him to hurry up until he came. He said to him: Where is your Master? He said: He is in a house here. He said: show me, knocked on the door, and opened it, and then entered it, and gave him succession ... (Yacoub, 1980). 
However, Abu Abbas did not forget his position, although he became the chief minister of the Abbasid state in his reign (Abu Salamah al-Khallal was not initially the minister of the Abbasid state, but was the minister of the call of the Abbasid call. Al-Tabari calls him (Minister of Imam) the Minister of Ibrahim Imam, the bomber of the Abbasid revolution.

And addressed by Abu Muslim Kharasani with the title of the emirate and the ministry. Ibrahim Al-Imam wrote to him before the year of $127 \mathrm{AH} / 744 \mathrm{AD}$ and calls him the call of the Hashemites and their minister. His nickname was Minister of Al-Mohammad, and he was not officially given the title. His powers were in conflict with the powers of the caliph Abu Abbas, Abu Musallam al-Kharasani and others, and Abu Salamah al-Khallal was only a consultant to the caliph (Yacoubi, 1939).

He said that Abu Abbas, when things were done and documented, consulted his ministers in the killing of Abu Salamah, they gave their opinions.

They said to him, "If you kill him, Abu Musallam will be suspicious, but the opinion is that you write to him what is the thing that made you doubting, and what is his interest from you getting discharged." Thus he did write to Abu Muslim about it.

When the book was presented to Abu Musallam, he wrote to Abu Abbas: If you get suspicious from him then make him lose his neck. When the book came to him, he said to him and his ministers: You do not believe that it is treacherous from Abu Musallam, and that he wants to find the way to what may makes you fear him, but write to him to send you a man from his leader to hit his neck.

So he wrote to him, and mentioned in his book: I do not offer or delay only in your opinion. Then he sent to him a man called Merar al-Dabbi. When he came to Abu Abbas, he ordered that al-Dabbi to sit in the darkness, inside the emirate in Kufa, if he got out he would hit him with the sword to cut his head, then ordered his crucifixion, and when the people came in the morning they found Abu Salamah crucified on the emirate.

(When Abu Abbas wanted to kill Abu Salamah because he tends to AL abi-Taleb ,Dawood said to him (Dawood bin Ali): Do not kill him and Abu Muslim gets angry from you, but write to him someone to kill him and he did, that was the right opinion, and praised Ibn Harma ( he has a Divan) and it says:

Dawood Dawood don't let his ropes and harden your hands with the rest of the friendliness and serenity.

The competition between Khallal and Abu Muslim played a role in the killing of Khallal in $133 \mathrm{AH}$.

When Abu Musallam al-Kharasani killed Abu Salamah, the security of al-Kufa was insured, and no longer feared from the opposition forces, although he changed his capital from Kufa to Anbar for its upper tendency, but with the death of Abu Salamah emptied the forces outside Kufa, especially in Khorasan.

After the slaughter managed to get rid of Abu Salamah, he sought to get rid of the rest of the preachers. Abu al-Abbas succeeded by pushing Abu Musallam al-Kharasani to kill the leaders of the Call in Khorasan one by one, and tried many times to kill Abu Musallam, these leaders, who were killed by Abu Muslim and were leaders of the Abbasid Call are:

Ibn al-Kirmani: the successor to Ali ibn al-Kirmani, his father Karamani leader of the tribes of Yemen and its allies and was Ibn al-Kirmani to the Abbasid call the point of separation that determined the fate of the revolution, and placed on the road to success, because these tribes were the basis of the army advanced to Iraq.

It was apparent that Ibn al-Kirmani did not know for sure that the Abbasid call was in the name of the Abbasid house, but he revolted in the name of "the satisfaction of the people of the house." But as soon as Abu Muslim managed to plot the assassination plot of Ibn al-Kirmani and his brother by his right- Ibrahim al-Zahli Shibani. (25)

Yazeed bin Abdullah bin Hubaira: A book from Yazid bin Abdullah bin Hubira to the pure-self telling him that he would sell him, and that he received money and several weapons, and that he had with him twenty thousand fighters; he sent the book to the slaughter so he ordered his death (26).

Mansur bin Jumhur: The caliph Abu al-Abbas appointed Mansour bin Jumhur, one of the leaders of the Abbasid revolution and the father of the Sindh in $132 \mathrm{AH}$. However, Abu Musallam sent the Al Mughals Alabdi to Sindh and Khurasan in violation of the caliph's order. Mansur threw on the Abbasids and their father Abu Musallam and killed Al Mughals ${ }^{*}$. Then in the year 134 Sgt. He sent Musa bin Ka'b to Sindh to fight Mansur bin Jumhur in four thousand ....

\footnotetext{
*Al-Yaqoubi says Abu Musallam's face is called "Mughals" by the people of Sajistan (Yacoubi, History, 2, p. 340).
} 
Khazim bin Khuzaymah: In the year $134 \mathrm{AH}$ when Khazem bin Khuzaymah went to eliminate the revolution of Bassam bin Ibrahim Kharasani, defeated Bassam and killed his heroes. Then Khazem passed through thirty of the Harthis, responsibled by the slaughter. He spoke to them in an order, and they were ashamed of him, so he killed them all.

The greatest of that is Yamaniyah and went to the slaughter shouting so he ordered to kill Khazim ibn Khuzaymah. They pointed to him with pardon. He has a precedent and obedience, and if the believer wanted to kill him, let him expose him to the invasion...

Ziad ibn Saleh: In the year 135 AH Ziad bin Saleh took off the obedience beyond the river, and prepared for his war, Abu Muslim Kharasani, and sent Nasr bin Saleh to Tarmz to be killed by a group of Kharijites, and Abu Muslim went to Aaml with him Sbaa bin Numan Azadi, who presented the era of Ziad bin Saleh On the one hand, and the slaughter ordered him to assassinate Abu Musallam if he managed.

Sulaiman bin Katheer Al-Khuzaie: Suleiman bin Katheer Al-Khuzaie and his son Muhammad were assassinated: It is known that Suleiman was the captain of the tribes and he has a wide tribal influence. He apparently called Abu Jaafar (brother of the caliph) when he visited Khorasan. They agreed to get rid of Abu Muslim. It might be the reason why they get rid of him.

Shrek bin Sheikh Al-Muhari: The partner of Sheikh Sheikh Al-Muhari in Bukhara opposed the Abbasid policy with the slogan "That is not why we followed Al-Muhammad, to shed blood, and to do without the right!."

The Abbasid caliph sent to Abu Musallam and sent Ziad ibn Saleh al-Khuzaie, who had difficulties in tracking down the rebels, which lead eventually to the failure Shrek, and the capture of a large number of his followers ... But the Abbasid Caliph understood the nature of this movement and its reasons. So they included a general amnesty and allowed them to return to their homes.

Issa bin Mahan: Abu Muslim participated with Khaled al-Zahli in the killing of Ziad bin Saleh al-Khuzai, who felt he was a rival after the revolution of Shrek and then killed Issa bin Mahan, one of the leaders of the Abbasid call for sympathy with Ziad. When the Caliph heard of the death of Isa, he denied that, and asked Abu Musallam to punish Khalid and kill him. But Abu Muslim sent a clear answer (for his intelligence and wit): "If the Ibn Mahan had been left, it would have been like Zayd ibn Saleh. And disagreement) and no action was taken against Khaled al-Mahli.

Farouq Fawzi described this response with intelligence. But his response was delayed because he was alone or did not see any of the leaders of the call as close to him as Khalid al-Thahli. Because at the end of the reign of Abu Abbas, Abu Muslim came out asking for pilgrimage. The slaughter allowed him at the same year he died;

In $136 \mathrm{AH}$ it was said: (Abu Muslim, the owner of the state wrote to the slaughter asking permission to come, he confirmed. then replaced by Khorasan Khalid ibn Ibrahim, and he was presented with a great reception. He was received by the princes, and the caliph honored him so he asked for pilgrimage.

The Caliph said: if Abu Jaafar weren't going to pilgrimage I would've put you in charge. Abu Jaafar was there at that time. So he said to him:" obey me and kill Abu Muslim. He is a perfidious person". He said:" I knew everything about him and what have he done."

Then he said, "How can we kill him?" He said: "If he came to you to talk, I would enter and hit his neck from behind," he said: "what about his friends who would sacrifice themselves to him?' He said: "once they know that he's dead they will despers". "I'm afraid if you didn't attack first then he would do it." Responsed: "he won't be able". Then got out. The slaughter send him a message not to do it. So he did not kill Abu Muslim during the reign of Abu Jaafar al-Mansur.

Ibn al-Kirmani represents a model for the preachers who were deceived by the nature of the call, which turned out to be Abbasid and not superior, and such advocates are no longer their role for the importance of the Abbasid state as long as their loyalty to the Abbasids,

His killing of Mansour bin Jumhur was the result of conflicting orders between the Caliph of absolute power, and one of the powerful leaders of the call Abu Muslim Kharasani. Khazim bin Khuzaymah represents the model of preachers who does not know the caliph, nor his family, nor the nature of the relationship, or the kinship that binds him with some tribes that may be supportive of him. The behavior of the slaughter with him was different. He did not want to appear as an avenger for his brothers. So he tried to remove him to engage in difficult battles so he may get killed in one of them and not by the Caliph.

Which indicates that the caliph did not see some preachers as a threaten to his powers, but to get rid of them as a result of their committed mistakes, and Ziad bin Saleh, who receded from obedience after he had pledged, which 
means that he didn't like the policy of the new state. It is noted that the slaughter took advantage of his departure to send Saba bin Nu'man al-Azadi not to eliminate it, but if he had the opportunity to get rid of Abu Muslim Kharasani. he was a commander commissioned with two tasks.

As for Sulayman al-Khuza'i - despite his great influence and his great proximity to the Abbasid family - Abu Muslim Kharasani worked to get rid of him, when he learned the consensual agreement with al-Mansur and their desire to get rid of him, either to kill him. The goal is to kill a man for a man he thinks he wants to kill.

While Ben Shiekh al-Muhri's partner shows his admiration for changing the concepts of the secret call when it appeared in public, this was not the reason why the Muhammad family followed him. Is it logical to kill Ziad al-Khuzaie, who spent a revolution against the state because Abu Muslim felt he was a rival to him, and to kill Issa bin Mahan because he sympathized with him?!

These leaders felt that the influence of Abu Muslim in Khurasan should be tightened, or that they felt threatened by him as well.

Therefore, Abu Abbas the slaughter did not eliminate the preachers in vain, but there was a justification for that, they weren't on the same position of the Abbasid state,

There are advocates which Abu Abbas the slaughter kept them close, and there are advocates found that the Caliphate did not follow the principles of advocacy, but on the contrary was deceptive and Abu Abbas alone bear the consequences of that change.

As for the preachers such as Abu Salamah and Abu Musallam, they were considered to have the power and authority to establish the rule of Abu Abbas. This authority was allowed by Abu Abbas to the advocates when he wanted to confirm his rule, not to be used by them to threaten him. So his opinion was to get rid of them.

The views on the elimination of the preachers are different and many, but there is no room for expansion here, and Abu Abbas had to either face the preachers or face members of his family or to guide them.

\section{Results}

The study shows the great difficulties faced by Abu al-Abbas al-Saffah in establishing the rules of the Abbasid state. It also shows the weaknesses and strengths of the Abbasid state, but shows the strength of Abu Abbas in the face of the opposing forces.

The preachers who were in the ranks of the call was supposed to not be fooled by the identity of the call or the Imam, but they are the only deceived themselves because they accepted to pledge without confirming the identity of the imam. The magic of the secret invitation was a source of attraction for many of them, but the identity of the imam was no longer so magical that the invitation itself was of little importance after that day.

The preachers rejected the end of the call in this way, that is, by showing the imam. It was important for them to continue this secrecy to maintain their allegiance to the Abbasid call, especially since many people are attracted by secrets or attracted by ambiguity about many of the issues they believe in or the countries they follow. Refers to the love of imagination and rejection of reality, which results in the impact of many people that imagination, and that the fate of two states ruled by it.

Abu al-Abbas's personal character, which replaced the Imam and other leaders of this state in general, was a surprise to many preachers and their appearance in this way is contrary to all the hopes and perceptions that the leaders painted ahead. His appearance means the emergence of all the human defects that the preachers could not imagine in their Imam.

On the other level, and on the ground can be said that the father of Abbas, the slaughter, all those forces with his mind not with his sword, did not raise his sword in the face of anyone, but he hit the strong one to the other, to ease the severity of the attack against him, Some may oppose this view given the scale of the revolutions against it.

The sword of Abu Musallam was only the sword of Abu Abbas the butcher, but we cannot ignore that some of the killing without reference to the Caliph in that.

While the short period ruled by the thief and his management of crises, the strength of his character, which was able to unite the Muslims under his banner in Iraq after a period of fighting and sedition, and the adaptation of people was not aware of their people and how they think,

And the achievement of political and religious acceptance in areas far from the region, where he was born and grew and did not know other countries in his youth, still he was able to adapt quickly with the change of conditions and places impact on the emergence of this state and install the pillars of those who came after him, especially that 
he received a large volume of opposition against originated His country has not been subjected to any other country preceded him to appear.

Therefore, it was necessary to follow all the forces supporting and opposing him, to know how the first Abbasid Caliph, who was not lacking the political savvy of dealing with it and was the reason for his success in eliminating revolutions and outlaws of the Abbasid call, but he cut the trunk of the tree did not cut roots because the seeds of these Crises emerged in the subsequent stages of his rule weakly in the era of Al-Rasheed, Al-Ameen, Al-Mamoon and Al-Mutawakil, until the era of the emperors of the era of the end of the Abbasid II.

\section{References}

Abd al-Razzaq, A. (1925). Islam and the Origins of Governance (Research on the Caliphate and the Government in Islam). Cairo: Egypt Press.

Abdul Aziz, L. (2014). The first Abbasid period (study in political history, administrative and financial). Center for Arab Unity Studies - Beirut - Lebanon. Yacoubi, Problems of people for their time.

Al-Masoudi, A. (1992). Abi Hassan Ali Bin Al Hussein Bin Ali Al Masoudi, Gold Promoters and Mineral, Al-kitab Al-Libnani house and the Library of the School / Beirut-Lebanon.

Al-Suyuti. (2005). History of the Caliphs.

Amin, A., \& Islam, D. (2001). C3, Dar al-Kitab al-Arabi Beirut-Lebanon.

Anonymous. (n.d.). The news of Abbas and his son, including the news of Abbas and his son (about a unique manuscript from the library of Abu Hanifa school - Baghdad, the investigation of Dr. Abdul Aziz Al-Douri, Dr. Abdul-Jabbar Al-Mutlibi, Dar Al-Tali'ah Beirut.

Farhoud, A. (1997). Investigation of Abdul Qadir Muhammad Mayo, a review by Ahmad Abdullah Farhoud, Dar Al-Qalam Al-Arabi - Halab, 1.

Fawzi, F. (2006). Islamic History. Research in systems and politics during the first Islamic centuries, Dar Majdlawi, Amman.

Fawzi, F. (2003). The First Abbasids. Revolution State Opposition C 1, Majdalawi - Amman Jordan.

Fawzi, F. (2002). Iraqi civilization, elite of Iraqi researchers. Faculty of Arts - University of Baghdad, C6, Ministry.

Fawzi, F. (1998). Iraqi civilization, elite of Iraqi researchers. Faculty of Arts - University of Baghdad.

Ibn Qutaiba, A. (1990). Imamate and Politics (known as the history of the caliphs). Investigation Ali Chery, House of Lights Beirut - Lebanon.

Ibn Jarir, A. (1966). History of the Tabari (History of the Apostles and Kings), the investigation of Muhammad Abu al-Fadl Ibrahim, M 7, Dar al-Ma'arif - Egypt, Suyuti, Jalaluddin Abdul Rahman bin Abi Bakr bin Mohammed, History of the Caliphs, Presentation by Abdullah Massoud, Dar Al-Qalam Al-Arabi - Aleppo, Dar Al-Fikr-Beirut, TZ239.

Ibn Tabataba, M. (1999). The honorary of the Royal Arts and Islamic States.

Ibn Qutaiba, A. (1990). Imamate and Politics (History of the Caliphs).

Ibn Qutaiba, A. (1969). Knowledge, achieved by Tharwat Okasha. Dar Al Ma'arif - Egypt.

Masoudi. (n.d.). Gold Promoter and Mineral (pp. 235-236).

Yacoubi, A. (2009). History of Islam and the Deaths of Celebrities and the Media, 1, Dar al-Gharb al-Islami, Tunis. Farouk Omar Fawzi, the first Abbasids.

Yacoubi, A. (1996). The investigation of Suhail Zoukar and Riyadh Zirkali. Dar al-Fikr Beirut, 1416 H 1996, c. 4, p. 118. Masoudi, gold promoter and mineral $\mathrm{m} 2$.

Yacoub, A. (1980). The problem of people for their time, the investigation of William Mollard. Beirut - Lebanon: The new book house.

Yacoubi, A. (1939). The history of Yacoubi, c 3, c 2. Najaf - The Library of Al-Marzawiyah. History of the Apostles and Kings. Masoudi, Gold Promoters and Mineral.

\section{Notes}

Note 1. The slaughter is Abu Abbas, Abdullah bin Mohammed bin Ali bin Abdullah ibn Abbas bin Abdul Muttalib bin Hashim. He was born in the year of one hundred, and was said in the year one hundred and one hundred. (See 
Baladhuri, camel of the genealogies, c. 4, p. 109.) It was said in the year of eight hundred ..., The History of the City of Peace, p. 11, p. 276. His mother Rita al-Harthyya, Al-Masoudi, Mawrouj Al-Zahab and Mineral Minerals, p.2, p. 234 Jalal al-Din al-Suyuti, History of the Caliphs, The people of the Arabs, p. 20, p. 114 And was Rita .... When Abdullah bin Abdul Malik bin Marwan died and then married after the pilgrims bin Abdul Malik bin Marwan and then divorced, and then married Mohammed bin Ali bin Abdul And his wife is Umm Salama bint Ya 'qub Ibn Salamah ibn al-Waleed ibn al-Mughayrah, the wife of Abu al-Abbas (al-Saffah), the dominant one is Umm Muhammad ibn al-Saffah Ibn Hazm al-Andalusi, 384-456, Al-Yazoor Al-Arabi, p. 148, first married Abdul Aziz ibn al-Walid bin Abdul Malik bin Marwan Amal Muhiuddin al-Kurdi, the role of women in the Abbasid Caliphate, Arabic edition 2014, Dar Al-Yazouri Scientific Amman-Jordan, pp. 29-30 and Bo'a in the year one hundred and thirty-two. Al-Masoudi mentioned, in the observation and supervision, only on the day of his death, $\mathrm{p}$. 339. Ibn Tabataba, Honorary of the Royal Arts and Islamic States, p. 147. He died in Anbar on Sunday, for the thirteenth of Dhu'l-Hijjah, ... and he was said to have died, thirty-three years old. Hisham ibn Muhammad said: It was the day of the death of the son of thirty-six years, and some of them said: He was twenty-eight years. His mandate was from the killing of Marwan bin Mohammed until he died four years, and from Bouayah to him succession until he died four years and eight months. Some said nine months. Al-Wakidi said: For four years and eight months and four days Marwan is fighting. Al-Tabari, History of the Apostles and Kings, c 7, 470-p. 471.

\section{Copyrights}

Copyright for this article is retained by the author(s), with first publication rights granted to the journal.

This is an open-access article distributed under the terms and conditions of the Creative Commons Attribution license (http://creativecommons.org/licenses/by/4.0/). 